\title{
Pengaruh Kompetensi Kepribadian dan Kompetensi Sosial terhadap Pelaksanaan Supervisi Akademik Pengawas Sekolah Menengah Atas
}

\author{
Triyanto Pristiwaluyo ${ }^{1}$, Fatimah Ab Hakim ${ }^{2}$ \\ Universitas Negeri Makassar \\ Email: triyantounm@gmail.com ${ }^{1}$, fatimahabhakim@gmail.com²
}

(Diterima: 12-Agustus-2018; di revisi: 15-Oktober-2018; dipublikasikan: 30-Desember-2018)

\begin{abstract}
ABSTRAK
Penelitian ini bertujuan untuk mengetahui kompetensi kepribadian, kompetensi sosial dan pelaksanaan supervisi akademik pengawas SMA serta pengaruh kompetensi kepribadian dan sosial terhadap pelaksanaan supervisi akademik yang dilakukan oleh pengawas SMA. Jenis penelitiannya adalah penelitian ex post facto. Populasi penelitian adalah semua guru tetap berstatus pegawai negeri sipil (PNS) pada SMA Negeri di Kabupaten Luwu. Sampel penelitian terdiri dari 152 orang guru yang diperoleh dengan teknik proportionale simple random sampling. Data penelitian ini dikumpulkan dengan menggunakan instrumen kompetensi sosial pengawas dan pelaksanaan supervisi akademik yang berbentuk kuesioner dengan skala model Likert. Teknik analisis data yang digunakan adalah analisis deskriptif dan analisis regresi ganda. Hasil penelitian menunjukkan bahwa: (1) Kompetensi kepribadian dan kompetensi sosial pengawas SMA ada pada kategori sangat tinggi dan tinggi, serta pelaksanaan supervisi akademik pengawas pada SMA berada pada kategori baik. Kompetensi kepribadian dan sosial pengawas pada SMA secara bersama-sama berpengaruh positif terhadap pelaksanaan supervisi akademik pengawas, dan Kompetensi kepribadian dan Kompetensi sosial pengawas masing-masing mempunyai pengaruh positif terhadap pelaksanaan supervisi akademik pengawas di SMA.
\end{abstract}

Kata kunci : kompetensi kepribadian, kompetensi sosial, pengawas, supervisi akademik.

\begin{abstract}
This study aims to determine personality competence, social competence and academic supervision of high school supervisors as well as the influence of personality and social competencies on the implementation of academic supervision conducted by high school supervisors. The type of research is ex post facto research. The study population was all permanent teachers with the status of civil servants (PNS) in State High Schools in Luwu Regency. The study sample consisted of 152 teachers obtained by the proportional simple random sampling technique. The data of this study were collected using the personality and social competency instruments of the supervisor and the implementation of academic supervision in the form of questionnaires with a Likert scale model. The data analysis technique used is descriptive analysis and multiple regression analysis. The results of the study indicate that: (1) the competence of personality and social competence of high school supervisors is in the very high and high category, and the implementation of supervisory academic supervision in high schools is in the good category. (2) The supervisory personality and social competencies in high school together have a positive effect on the supervisory academic supervision, and (3) Personality competency and supervisory social competence each have a positive influence on the implementation of supervisory academic supervision in high school.
\end{abstract}

Keywords: personality competence, social competence, supervisor, academic supervision

Copyright (C) 2018 Universitas Negeri Makassar. This is an open access article under the CC BY license (http://creativecommons.org/licenses/by/4.0/) 


\author{
64 Jurnal Administrare: Jurnal Pemikiran Ilmiah dan Pendidikan Administrasi Perkantoran \\ Volume 5 Nomor 2 Juli-Desember 2018. Hal 63-76
}

\title{
PENDAHULUAN
}

Dalam Peraturan Pemerintah Republik Indonesia Nomor 32 Tahun 2013 tentang Standar Nasional Pendidikan sebagai perubahan dari Peraturan Pemerintah Republik Indonesia Nomor 19 Tahun 2005 tentang Standar Nasional Pendidikan, pada pasal 55 dinyatakan bahwa tugas kepengawasan satuan pendidikan meliputi pemantauan, supervisi, evaluasi, pelaporan dan tindak lanjut hasil pengawasan(Amanda, Salam, \& Saggaf, 2017). Selanjutnya dalam pasal 57 dinyatakan bahwa supervisi meliputi supervisi manajerial dan akademik.

Berdasarkan ketentuan tersebut, maka tugas pokok pengawas adalah: 1) melaksanakan supervisi akademik dan supervisi manajerial pada satuan pendidikan dan, 2) melaksanakan pembimbingan dan pelatihan profesional guru (Sudjana, 2012). Supervisi akademik bertujuan untuk memperbaiki kualitas pembelajaran dengan memberikan bimbingan kepada guru dan konselor. Pelaksanaan supervisi akademik oleh pengawas sekolah dilakukan melalui tiga kegiatan, yaitu pemantauan, penilaian dan pembimbingan tugas pokok guru (Sudjana, 2011).

Kehadiran pengawas di sekolah binaan lebih sering bertemu dengan kepala sekolah, dibandingkan melakukan pemantauan dan pembinaan langsung terhadap guru. Kegiatan supervisi yang dilakukan oleh pengawas kebanyakan berorientasi pada aspek kepengawasan (kontrol) dan obyek utamanya adalah administrasi, sehingga kurang tercipta suasana kemitraan antara guru dan supervisor. Seyogyanya antara pengawas, kepala sekolah, dan guru terjalin hubungan kerja secara harmonis, sinergis, dan saling mendukung satu sama lain sesuai dengan peran dan tugas masing-masing (Agung Iskandar, 2013).

Salah satu langkah yang harus ditempuh pengawas sekolah dalam melakukan pembinaan kemampuan profesional guru melalui kegiatan supervisi akademik adalah menciptakan hubungan yang harmonis, dengan kepala sekolah, guru, dan semua pihak yang terkait di sekolah (Sudjana, 2011: 106). Dengan terciptanya hubungan yang harmonis diantara pengawas, kepala sekolah, dan guru; maka pelaksanaan supervisi akademik dapat berjalan dengan baik dan diharapkan akan menghasilkan pembinaan yang optimal.

Pengawas sekolah masih terfokus pada pelaksanaan tugas guna memenuhi beban dan administrasi kerja, belum disertai dengan upaya untuk mendukung dan meningkatkan kegiatan pembelajaran pihak-pihak yang disupervisi di sekolah (Akib \& Saleh, 2015; Cattelino, Morelli, Baiocco, \& Chirumbolo, 2019; Inprasitha, 2014; Irvin, Ingram, Huffman, Mason, \& Wills, 2018; Montecinos, Walker, \& Maldonado, 2015). Keadaan tersebut berdampak pada etos kerja guru yang cenderung stagnan, pasif, kurang kreatif, karena tidak atau kurang memperoleh bantuan dan bimbingan dari kepala sekolah dan pengawas. Pengawas sekolah dituntut untuk memberikan bimbingan kepada guru melalui layanan supervisi pembelajaran. Masaong (2013: 3) menjelaskan pengertian supervisi pembelajaran adalah "pelayanan yang disediakan oleh pemimpin untuk membantu guru-guru agar menjadi guru atau personal yang semakin cakap sesuai dengan perkembangan ilmu pengetahuan pada umumnya dan ilmu pendidikan khususnya, agar mampu meningkatkan efektivitas proses belajar mengajar di sekolah". Lebih luas Kimball Wiles (Sahertian. 2010: 18) menjelaskan bahwa keberhasilan supervisi atau bantuan yang diberikan untuk memperbaiki situasi belajar-mengajar di sekolah tergantung kepada keterampilan supervisor sebagai pemimpin. 
Supervisi dari segi perubahan sosial yang berpengaruh terhadap peserta didik seperti yang dikemukakan Burton dan Bruckner (Sahertian, 2000) adalah suatu teknik pelayanan yang tujuan utamanya mempelajari dan memperbaiki secara bersama-sama faktor-faktor yang mempengaruhi pertumbuhan dan perkembangan anak. Permendiknas RI No 12 tahun 2007 tentang kompetensi pengawas sekolah menegaskan bahwa pengawas sekolah harus memiliki kompetensi sebagai seorang pengawas sekolah. Kompetensi pengawas satuan pendidikan/pengawas sekolah adalah seperangkat kemampuan yang mencakup pengetahuan, keterampilan, dan sikap yang harus dimiliki pengawas sekolah secara terpadu dan ditampilkan dalam tindakannya untuk peningkatan mutu pendidikan pada satuan pendidikan/sekolah yang menjadi binaannya (Amanda et al., 2017; Sudjana, 2011).

Kompetensi pengawas satuan pendidikan mencakup enam dimensi kompetensi. Substansi materi keilmuan pada dimensi kepribadian dan sosial lebih ditekankan kepada pendalaman dan penghayatan nilai-nilai yang diperlukan pengawas sekolah/madrasah atas penguatan jati dirinya sebagai pribadi dan anggota masyarakat yang dapat diteladani guru, kepala sekolah dan masyarakat (Sudjana, 2012: 60).

Kompetensi sosial pengawas adalah kompetensi yang mendasari seluruh kompetensi lainnya, karena berkaitan dengan aspek nilai dan sikap serta motivasi dan komitmen. Kompetensi sosial pengawas sekolah adalah kemampuan pengawas sekolah dalam mengembangkan jaringan kemitraan dengan berbagai pihak yang terkait dengan peningkatan mutu sekolah dan mengembangkan tim kerjasama yang kokoh di dalam sekolah serta menyelesaikan konflik di sekolah dalam rangka meningkatkan kualitas diri (Depdiknas, 2009: $1)$.

Kompetensi sosial pengawas sekolah mengindikasikan dua keterampilan yang harus dimiliki pengawas sekolah yakni : (1) keterampilan berkomunikasi baik lisan atau tulisan termasuk keterampilan bergaul dan (2) keterampilan bekerja dengan orang lain baik secara individu maupun secara kelompok/organisasi. Keterampilan ini mensyaratkan tampilnya sosok pribadi pengawas yang luwes, terbuka, mau menerima kritik serta selalu memandang positif orang lain.

Pengawas diharapkan memiliki kompetensi sosial, khususnya dalam menjalin mitra dengan para kepala sekolah, guru, shareholder dan stakeholder lainnya. Hal ini karena dalam bekerja pengawas bertemu banyak orang dengan berbagai latar belakang, kondisi, kepentingan serta persoalan yang dihadapi. Mereka juga harus mampu bermitra baik dengan individu maupun kelompok, selain itu pengawas juga berperan untuk mengembangkan jaringan kemitraan dengan berbagai pihak yang terkait dengan peningkatan mutu sekolah, dan mengembangkan tim kerjasama yang kokoh di dalam sekolah (Depdiknas, 2009: 1). Dengan bantuan yang diberikan pengawas kepada guru, maka guru dapat memperbaiki cara mengajarnya dan peserta didik mendapat layanan belajar yang lebih efektif dan berkualitas. Dengan demikian maka permsalahannya adalah kompetensi sosial pengawas menurut persepsi guru, pelaksanaan supervisi akademik pengawas, dan pengaruh kompetensi sosial terhadap pelaksanaan supervisi akademik pengawas. 


\section{Jurnal Administrare: Jurnal Pemikiran Ilmiah dan Pendidikan Administrasi Perkantoran Volume 5 Nomor 2 Juli-Desember 2018. Hal 63-76}

\section{METODE}

Penelitian ini menggunakan pendekatan kuantitatif, jenis penelitian ex post facto dengan metode survei. Variabel yang diteliti adalah kompetensi sosial pengawas dan pelaksanaan supervisi akademik pengawas. Penelitian ini dilaksanakan pada SMA Negeri di Kabupaten Luwu.

Populasi dalam penelitian ini adalah guru PNS pada 8 SMA Negeri di Kabupaten Luwu berjumlah 244 guru. Sampel dalam penelitian ini diperoleh dengan menggunakan teknik Proportionale simple random sampling. Jumlah guru pada setiap sekolah diperoleh dengan menggunakan formula Slopin dengan tingkat margin 5\%. Peneliti mengambil sampel sebesar 152 atau $62,3 \%$ dari jumlah populasi. Teknik pengumpulan data untuk variabel kompetensi sosial pengawas serta pelaksanaan supervisi akademik pengawas menggunakan instrumen berupa kuesioner skala model Likert dengan responden guru. Indeks validitas isi instrumen penelitian variabel kompetensi sosial pengawas sebesar 0,94 dan variabel pelaksanaan supervisi akademik pengawas sebesar 0,91 .

Analisis data yang digunakan dalam penelitian ini adalah analisis data deskriptif dan analisis data inferensial. Analisis deskriptif digunakan untuk mendeskripsikan data masingmasing variabel. Data dikelompokkan dalam 4 kategori, dengan ketentuan sebagai berikut:

$$
\begin{array}{ll}
X<\bar{X}-\mathbf{1}, \mathbf{5} . S & \text { Sangat Rendah/Kurang } \\
\bar{X}-\mathbf{1}, \mathbf{5 . S} \leq X<\bar{X} & \text { Rendah/Sedang } \\
\bar{X} \leq X<\bar{X}+\mathbf{1}, \mathbf{5} . S & \text { Tinggi/Baik } \\
X \geq \bar{X}+\mathbf{1}, \mathbf{5} . S & \text { Sangat Tinggi/Amat Baik }
\end{array}
$$

(Mardapi, D. 2012: 162)

Analisis inferensial digunakan dalam pengujian hipotesis penelitian, menggunakan analisis regresi ganda. Perhitungan dilakukan dengan menggnakan bantuan program siap pakai SPSS for windows.

\section{HASIL PENELITIAN DAN PEMBAHASAN}

\section{Hasil Penelitian}

\section{Analisis deskriptif kompetensi kepribadian pengawas SMA}

Hasil analisis menunjukkan variabel persepsi guru terhadap kompetensi kepribadian pengawas, disajikan dalam tabel 1. 
Tabel 1.

Ukuran Statistik Deskriptif Variabel Kompetensi Kepribadian Pengawas

\begin{tabular}{l|c}
\hline Ukuran Statistik & Skor \\
\hline $\mathrm{N}$ & 152 \\
Minimum & 65 \\
Maksimum & 119 \\
Rerata & 98,54 \\
Median & 100 \\
Standar Deviasi & 11,56 \\
Varian & 133,56 \\
\hline
\end{tabular}

Median sebesar 100 menunjukkan bahwa 50\% pengawas di Kabupaten Luwu memiliki skor kompetensi kepribadian pengawas 100,00 ke atas dan 50\% di bawah 100. Sedangkan varians sebesar 133,69, dan standar Luwu memiliki skor kompetensi kepribadian pengawas 100,00 ke atas dan 50\% di bawah 100. Sedangkan varians sebesar 133,69,dan standar deviasi sebesar 11,56 dengan rentang skor 54 mengindikasikan bahwa kompetensi kepribadian pengawas di Kabupaten Luwu cenderung menyebar dengan skor minimum 65 dan skor maksimum 119. Distribusi skor dan persentase kompetensi kepribadian pengawas diperlihatkan pada tabel 2 .

Tabel 2.

Kategori kompetensi kepribadian pengawas pada SMA

\begin{tabular}{rllc}
\hline \multicolumn{1}{l}{ Rentang Skor } & Kategori & f & $\%$ \\
\hline$X<52,50$ & Sangat Rendah & 0 & $0,00 \%$ \\
$52,50 \leq X<75,00$ & Rendah & 5 & $0,29 \%$ \\
$75,00 \leq X<97,50$ & Tinggi & 65 & $42,76 \%$ \\
$X \geq 97,50$ & Sangat Tinggi & 82 & $53,94 \%$ \\
\hline
\end{tabular}

Berdasarkan hasil analisis tersebut dapat disimpulkan bahwa kompetensi kepribadian pengawas pada SMA di Kabupaten Luwu menurut persepsi guru pada umumnya berada pada kategori sangat tinggi.

\section{Analisis deskriptif kompetensi sosial pengawas SMA}

3.

Hasil analisis menunjukkan variabel kompetensi sosial pengawas, disajikan dalam tabel 
Tabel 3.

Ukuran Statistik Deskriptif Variabel Kompetensi Sosial Pengawas

\begin{tabular}{l|c}
\hline Ukuran Statistik & Skor \\
\hline $\mathrm{N}$ & 152 \\
Minimum & 48 \\
Maksimum & 119 \\
Rerata & 88,86 \\
Median & 89,00 \\
Standar Deviasi & 12,90 \\
Varian & 166,45 \\
\hline
\end{tabular}

Hasil analisis data kuesioner penelitian pada kompetensi sosial pengawas, diperoleh bahwa skor terendah adalah 48 dan skor tertinggi adalah 119. Rerata skor kompetensi sosial pengawas sebesar 88,86; Median sebesar 89,00 menunjukkan bahwa 50\% pengawas di Kabupaten Luwu memiliki skor kompe tensi sosial 89 atau lebih di atas rerata, dan $50 \%$ di bawah 89. Standar deviasi sebesar 12,90; dan varian sebesar 166,45. dengan rentang skor 71 mengindikasikan bahwa kompetensi sosial pengawas di Kabupaten Luwu cenderung menyebar dengan skor minimum 48 dan skor maksimum 119. Distribusi skor dan persentase kompetensi sosial pengawas diperlihatkan pada tabel 4 .

Tabel 4.

Kategori kompetensi sosial pengawas pada SMA

\begin{tabular}{cllc}
\hline Rentang Skor & Kategori & f & $\%$ \\
\hline$X<47,25$ & Sangat Rendah & 1 & $0,66 \%$ \\
$47,25 \leq X<67,50$ & Rendah & 17 & $11,18 \%$ \\
$67,50 \leq X<87,75$ & Tinggi & 90 & $59,21 \%$ \\
$X \geq 7,75$ & Sangat Tinggi & 44 & $28,95 \%$ \\
\hline
\end{tabular}

Berdasarkan hasil analisis tersebut dapat disimpulkan bahwa kompetensi sosial pengawas di Kabupaten Luwu pada umumnya adalah tinggi.

\section{Analisis Deskriptif Pelaksanaan Supervisi Akademik Pengawas SMA}

Hasil analisis menunjukkan variabel Pelaksanaan Supervisi Akademik Pengawas, disajikan dalam tabel 5. 
Tabel 5.

Ukuran Statistik Deskriptif Variabel Kompetensi Sosial Pengawas

\begin{tabular}{l|c}
\hline Ukuran Statistik & Skor \\
\hline $\mathrm{N}$ & 152 \\
Minimum & 74 \\
Maksimum & 176 \\
Rerata & 128,65 \\
Median & 130,00 \\
Standar Deviasi & 23,27 \\
Varian & 541,83 \\
\hline
\end{tabular}

Rerata skor pelaksanaan supervisi akademik pengawas sebesar 128,65; dan median sebesar 130,00 menunjukkan bahwa lebih dari 50\% pengawas di Kabupaten Luwu memiliki skor pelaksanaan supervisi akademik diatas rata-rata. Standar deviasi sebesar 23,277; dan varian sebesar 541,833 mengindikasikan bahwa pelaksanaan supervisi akademik pengawas di Kabupaten Luwu cenderung menyebar dengan skor minimum 74 dan skor maksimum 176. Distribusi skor dan persentase kompetensi kepribadian pengawas diperlihatkan pada tabel 6 berikut.

Tabel 6.

Kategori pelaksanaan supervisi akademik Pengawas pada SMA

\begin{tabular}{clll}
\hline Rentang Skor & Kategori & f & \multicolumn{1}{c}{$\%$} \\
\hline$X<73,50$ & Kurang & 3 & $1,97 \%$ \\
$73,50 \leq X<105,00$ & Sedang & 28 & $18,42 \%$ \\
$105,00 \leq X<136,50$ & Baik & 75 & $49,34 \%$ \\
$X \geq 136,50$ & Amat Baik & 46 & $30,26 \%$ \\
\hline
\end{tabular}

Berdasarkan tabel 6 diatas dapat disimpulkan bahwa pelaksanaan supervisi akademik pengawas pada SMA di Kabupaten Luwu pada umumnya adalah baik.

\section{Pengujian Hipotesis}

Pengujian hipotesis penelitian tentang pengaruh kompetensi kepribadian dan sosial secara bersama-sama terhadap pelaksanaan supervisi akademik pengawas dilakukan melalui analisis inferensial yaitu analisis regresi ganda. Hasil analsis pada tampilan output Model Summary terlihat besarnya $R=0,823$, maka besarnya koefesien determinasi $\left(R^{2}\right)$ adalah $67,7 \%$.

Hal ini menunjukkan bahwa korelasi yang secara simultan antara variabel kompetensi kepribadian pengawas $\left(X_{I}\right)$ dan kompetensi sosial pengawas $\left(X_{2}\right)$ terhadap variabel pelaksanaan 


\section{Jurnal Administrare: Jurnal Pemikiran Ilmiah dan Pendidikan Administrasi Perkantoran Volume 5 Nomor 2 Juli-Desember 2018. Hal 63-76}

supervisi akademik pengawas $(Y)$ adalah tinggi. Kontribusi (daya ramal) yang diberikan oleh kedua variabel $\left(X_{I}\right)$ dan $\left(X_{2}\right)$ terhadap variabel $(Y)$ sebesar $67,7 \%$. Hal ini berarti $67,7 \%$ variasi dari variabel $(Y)$ bisa dijelaskan oleh variasi kedua variabel $\left(X_{I}\right)$ dan $\left(X_{2}\right)$, sedangkan sisanya sebesar 32,3\% dijelaskan oleh sebab-sebab yang lain.

\section{Pengujian hipotesis tentang pengaruh kompetensi kepribadian pengawas $\left(X_{I}\right)$ kompetensi sosial pengawas $\left(X_{2}\right)$ secara bersama-sama terhadap pelaksanaan supervisi akademik pengawas $(Y)$}

Pengujian hipotesis dilakukan melalui uji signifikansi persamaan regresi ganda dengan Uji- $F$. Di samping itu juga dilakukan uji-t untuk menentukan apakah variabel $\left(X_{I}\right)$ dan $\left(X_{2}\right)$ berpengaruh secara parsial terhadap $(Y)$.

Hipotesis yang diuji :

$H_{0}$ : Tidak terdapat pengaruh yang signifikan secara simultan antara kompetensi kepribadian $\left(X_{I}\right)$ dan sosial pengawas $\left(X_{2}\right)$ terhadap pelaksanaan supervisi akademik pengawas $(Y)$

$H_{l}$ : Terdapat pengaruh yang signifikan secara simultan antara kompetensi kepribadian $\left(X_{I}\right)$ dan $H_{0}: \beta=0$ sosial pengawas $\left(X_{2}\right)$ terhadap pelaksanaan supervise akademik pengawas $(Y)$

$H_{1}: \beta \neq 0$

Hasil perhitungan menggunakan bantuan program SPPS, diperoleh rangkuman Anava. Rangkuman tersebut disajikan dalam tabel 7.

Tabel 7.

Rangkuman Anava pengaruh simultan kompetensi kepribadian dan sosial pengawas terhadap pelaksanaan supervisi akademik pengawas

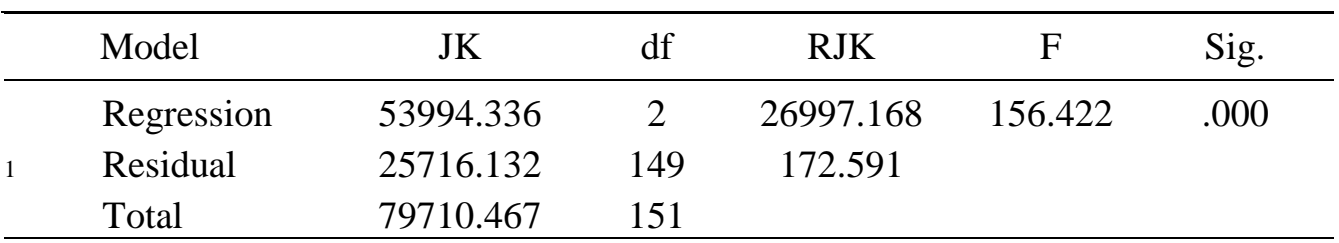

Hasil analisis pada tabel 6 , diketahui nilai $\mathrm{F}_{\text {hitung }}=156,42$ pada $\mathrm{df}=2 / 151$ dengan nilai signifikansi $p=0,001$. Nilai $p=0,001<\alpha=0,05$, maka Ho ditolak. Dengan demikian dapat disimpulkan bahwa terdapat pengaruh yang signifikan secara simultan antara kompetensi kepribadian $\left(\mathrm{X}_{1}\right)$ dan sosial pengawas $\left(\mathrm{X}_{2}\right)$ terhadap pelaksanaan supervise akademik pengawas (Y). Selanjutnya dilakukan uji-t uji-t untuk mengetahui signifikansi tingkat keberartian variabel bebas dari kompetensi kepribadian pengawas yaitu $b_{l}$ dan variabel bebas dari kompetensi sosial pengawas yaitu $b_{2}$. Hipotesis yang diuji adalah sebagai berikut.

$H_{0}$ : koefisien regresi dalam model tidak berarti

$H_{l}$ : koefisien regresi dalam model berarti 
Hasil perhitungan dengan SPSS dirangkum dalam tabel 8.

Tabel 8.

Rangkuman Hasil analisis koefesien regresi ganda

\begin{tabular}{|c|c|c|c|c|c|}
\hline \multirow{2}{*}{ Model } & \multicolumn{2}{|c|}{$\begin{array}{l}\text { Unstandardized } \\
\text { Coefficients }\end{array}$} & \multirow{2}{*}{$\begin{array}{c}\begin{array}{c}\text { Standardized } \\
\text { Coefficients }\end{array} \\
\text { Beta }\end{array}$} & \multirow[t]{2}{*}{$\mathrm{t}$} & \multirow{2}{*}{ Sig. } \\
\hline & B & Std. Error & & & \\
\hline (Constant) & -20.939 & 9.231 & & -2.268 & .025 \\
\hline $\begin{array}{l}\text { Kompetensi } \\
\text { Kepribadian }\end{array}$ & .521 & .128 & .262 & 4.059 & .000 \\
\hline $\begin{array}{l}\text { Pengawas } \\
\text { Kompetensi Sosial } \\
\text { Pengawas }\end{array}$ & 1.150 & .120 & .620 & 9.597 & .000 \\
\hline
\end{tabular}

Dari hasil analisis seperti disajikan dalam tabel 6 , diperoleh $\mathrm{t}_{1}=4,059$ dengan nilai signifikansi $p<0,001$ yang jauh lebih kecil dari $\alpha=0,05$. Dengan demikian maka Ho ditolak, atau dengan kata lain bahwa koefisien regresi $b_{1}$ signifikan. Untuk $\mathrm{t}_{2}=9,597$ dengan nilai signifikansi $p<0,001$ yang juga jauh lebih kecil dari $\alpha=0,05$. Hal ini menunjukkan bahwa koefisien regresi $b_{2}$ signifikan. Dengan demikian dapat disimpulkan bahwa kompetensi kepribadian pengawas $\left(X_{1}\right)$ dan kompetensi sosial pengawas $\left(X_{2}\right)$ secara bersama-sama berpengaruh positif terhadap pelaksanaan supervisi akademik pengawas $(Y)$ di Kabupaten Luwu. Dengan demikian maka dapat ditulis persamaan regresi ganda sebagai berikut :

$\widehat{\mathrm{Y}}=-20,939+0,521 \mathrm{X}_{1}+1,150 \mathrm{X}_{2}$

Dari persamaan regresi ganda tersebut dapat diketahui bahwa nilai konstan untuk pelaksanaan supervisi akademik pengawas pada SMA di Kabupaten Luwu $(Y)$ adalah $\quad-20,939$, ini berarti bahwa apabila variabel independen, kompetensi kepribadian $\left(X_{I}\right)$ dan kompetensi sosial $\left(X_{2}\right)$ diasumsikan sama dengan 0 (nol) maka variabel dependen $(Y)$ sama dengan -20,939. Diketahui pula bahwa nilai koefisien regresi ganda variabel $X_{1}$ sebesar 0,521 dan $X_{2}$ sebesar 1,150 . Hal ini menunjukkan kompetensi kepribadian dan kompetensi sosial berpengaruh positif terhadap pelaksanaan supervisi akademik pengawas pada SMA di Kabupaten Luwu. Apabila variabel $X_{1}$ dan $X_{2}$ diberi perhatian satu satuan maka akan terjadi perubahan pola postif terhadap pelaksanaan supervisi akademik pengawas sebesar nilai koefisien $(Y)$ yaitu sebesar 0,521 dan 1,150 .

2. Pengujian hipotesis tentang pengaruh kompetensi kepribadian pengawas $\left(X_{I}\right)$ terhadap pelaksanaan supervisi akademik pengawas $(Y)$ dengan memperhitungkan variabel kompetensi sosial pengawas $\left(X_{2}\right)$

Pengujian hipotesis tentang pengaruh variabel kompetensi kepribadian pengawas $\left(\mathrm{X}_{1}\right)$ terhadap pelaksanaan supervisi akademik, maka pengaruh varibel kompetensi sosial $\left(\mathrm{X}_{2}\right)$ harus dikendalikan, dengan cara melakukan uji signifikansi regresi ganda secara parsial dengan uji-t. 


\section{Jurnal Administrare: Jurnal Pemikiran Ilmiah dan Pendidikan Administrasi Perkantoran Volume 5 Nomor 2 Juli-Desember 2018. Hal 63-76}

Hipotesis yang diuji seperti:

$\mathrm{H}_{0}$ : tidak terdapat pengaruh yang signifikan secara parsial kompetensi kepribadian pengawas (X1) terhadap pelaksanaan supervisi akademik pengawas (Y).

$\mathrm{H}_{1}$ : terdapat pengaruh yang signifikan secara parsial kompetensi kepribadian pengawas (X1) terhadap pelaksanaan supervisi akademik pengawas (Y).

$\mathrm{H} 0: \beta_{1}=0$

$\mathrm{H} 1: \beta_{1} \neq 0$

Hasil perhitungan sebagaimana disajikan dalam tabel 6 , terlihat bahwa nilai thiung pada koefesien regresi b1 sebesar 4,050 dengan nilai $\mathrm{p}=0,000$ yang lebih kecil dari $\alpha=0,05$ maka Ho ditolak, artinya koefisien regresi $b_{1}=0,521$ adalah signifikan. Dengan demikian dapat disimpulkan bahwa terdapat pengaruh yang signifikan secara parsial kompetensi kepribadian pengawas $\left(X_{l}\right)$ terhadap pelaksanaan supervisi akademik pengawas $(Y)$.

Dilihat dari hasil analisis korelasi pasial antara variabel kompetensi kepribadian pengawas $\left(X_{I}\right)$ terhadap pelaksanaan supervisi akademik pengawas $(Y)$, dengan mengontrol variabel kompetensi sosial pengawas (X2) diperoleh $\mathrm{R}_{\mathrm{y} 1.2}=0,423$ dengan nilai $p=0,001<\alpha=$ 0,05 . Artinya korelasi signifikan. Koefisien Determinasi $\mathrm{R}_{\mathrm{y} 1.2}{ }^{2}=0,179$, menunjukkan bahwa sebesar $17,9 \%$ variasi $(Y)$ yang dapat dijelaskan oleh variabel kompetensi kepribadian pengawas dengan mengontrol variabel kompetensi sosial pengawas.

\section{Pengujian hipotesis tentang pengaruh kompetensi sosial pengawas $\left(X_{2}\right)$ terhadap pelaksanaan supervisi akademik pengawas $(Y)$ dengan memperhitungkan variabel kompetensi kepribadian pengawas $\left(X_{I}\right)$}

Pengujian hipotesis tentang pengaruh variabel kompetensi sosial pengawas (X2) terhadap pelaksanaan supervisi akademik, maka pengaruh varibel kompetensi kepribadian (X1) harus dikendalikan, dengan cara melakukan uji signifikansi regresi ganda secara parsial dengan uji-t. Hipotesis yang diuji adalah sebagai berikut

$H_{0}$ : tidak terdapat pengaruh yang signifikan secara parsial kompetensi sosial pengawas $\left(X_{2}\right)$ terhadap pelaksanaan supervisi akademik pengawas $(Y)$.

$H_{i}$ : terdapat pengaruh yang signifikan secara parsial kompetensi sosial pengawas $\left(X_{2}\right)$ terhadap pelaksanaan supervisi akademik pengawas $(Y)$.

$H_{0}: \beta_{2}=0$

$H_{1}: \beta_{2} \neq 0$

Hasil perhitungan sebagaimana disajikan dalam tabel 6 , terlihat bahwa nilai $t_{\text {hiung }}$ pada koefesien regresi $b_{2}$ sebesar 9,597 dengan nilai $\mathrm{p}=0,000$ yang lebih kecil dari $\alpha=0,05$ maka Ho ditolak, artinya koefisien regresi $b_{2}=1,150$ adalah signifikan. Dengan demikian dapat disimpulkan bahwa terdapat pengaruh yang signifikan secara parsial kompetensi sosial pengawas $\left(X_{2}\right)$ terhadap pelaksanaan supervisi akademik pengawas $(Y)$.

Dilihat dari hasil analisis korelasi pasial antara variabel kompetensi sosial pengawas $\left(X_{2}\right)$ terhadap pelaksanaan supervisi akademik pengawas $(Y)$, dengan mengontrol variabel kompetensi kepribadian pengawas (X1) diperoleh $\mathrm{R}_{\mathrm{y} 2.1}=0,611$ dengan nilai $p=0,001<\alpha=$ 0,05 . Artinya korelasi signifikan. Koefisien Determinasi $\mathbf{R}_{\mathrm{y} 1.2}{ }^{2}=0,371$, menunjukkan bahwa 
sebesar $37,3 \%$ variasi $(Y)$ yang dapat dijelaskan oleh variabel kompetensi sosial pengawas dengan mengontrol variabel kompetensi kepribadian pengawas.

\section{Pembahasan}

Hasil analisis deskriptif menunjukkan bahwa kompetensi kepribadian pengawas berada pada kategori sangat tinggi, kompetensi sosial pengawas berada pada kategori tinggi dan pelaksanaan supervisi akademik pengawas berada pada kategori baik. Hasil analisis yang dilakukan pada pengujian hipotesis disimpulkan bahwa variabel kompetensi kepribadian dan sosial pengawas berpengaruh positif terhadap pelaksanaan supervisi akademik pengawas. Hal tersebut mengindikasikan bahwa apabila kompetensi kepribadian dan sosial pengawas meningkat maka pelaksanaan supervisi akademik pengawas akan meningkat pula. Hasil analisis juga menunjkkan nilai koefesien korelasi ganda $R=0,823$ sehingga koefesien determinasi $R^{2}=$ 0,667 . Hal ini mengindikasikan bahwa sekitar $67,7 \%$ variasi pelaksanaan supervisi akademik pengawas dapat dijelaskan oleh varibel kompetensi kepribadian dan kompetensi sosial pengawas secara bersama-sama. Sehingga dapat dinyatakan bahwa kompetensi kepribadian dan sosial pengawas berpengaruh terhadap pelaksanaan supervisi akademik pengawas.

Hal ini sekaligus membenarkan teori dari Depdiknas (2009: 1) yang mengatakan kompetensi kepribadian dan sosial pengawas merupakan kompetensi yang mendasari seluruh kompetensi lainnya, karena berkaitan dengan aspek nilai dan sikap serta motivasi dan komitmen. Hal ini menunjukkan bahwa kompetensi sosial dan kepribadian merupakan hal utama yang diperlukan dalam membangun kinerja organisasi.

Hal ini pula sejalan dengan yang diteliti oleh (Kadarsih, 2014) yang menyatakan bahwa secara simultan dan parsial, pengaruh variabel profesionalisme dan kompetensi auditor terhadap kinerja auditor berpengaruh nyata, dan hubungannya positif.

Pekerja yang kompeten cenderung memperlihatkan kinerja dan hasil kerja yang memadai, dan begitu pula sebaliknya, hal ini diungkapkan oleh (Agung Iskandar, 2013). Dalam hal kinerja, Ferris, Munyon, Basik, \& Buckley (2008) menyimpulkan bahwa mekanisme suatu kinerja terdiri dari komponen sosial, kepribadian, pengetahuan, politik dan hubungan relasi. Hal ini menunjukkan bahwa hubungan sosial dan pribadi yang mantap seorang pengawas sekolah akan sangat menunjang pelaksanaan supervisi akademik di sekolah. Pelaksanaan supervisi akademik yang baik akan meningkatkan kualitas pembelajaran dan mutu pendidikan di daerah yang pada gilirannya akan meningkatkan mutu pendidikan nasional.

Menurut Sagala (2010) bahwa Pengawas yang sukses melaksanakan tugasnya, jika ia memiliki sifat-sifat kepribadian yang diterima dalam pergaulan sesama kerabat kerja. Aspek kepribadian sangat menunjang keberhasilan seorang pengawas sekolah dalam melaksanakan tugas dan fungsinya. Aspek sosial membantu meningkatkan kualitas supervisi dan mampu mengatasi berbagai problem pendidikan dan pengajaran dengan baik. Dalam hal ini kinerja yang dilakukan oleh pengawas dalam melaksanakan kegiatan supervisi akademik telah dipengaruhi oleh kompetensi kepribadian dan sosial pengawas.

Hasil analisis inferensial dengan uji korelasi parsial menunjukkan adanya arah hubungan yang positif antara kompetensi kepribadian pengawas dengan pelaksanaan supervisi akademik pengawas sekolah dengan memperhitungkan kompetensi sosial pengawas sekolah. Dengan 


\section{Jurnal Administrare: Jurnal Pemikiran Ilmiah dan Pendidikan Administrasi Perkantoran Volume 5 Nomor 2 Juli-Desember 2018. Hal 63-76}

demikian semakin tinggi kompetensi kepribadian pengawas maka semakin baik pula pelaksanaan supervisi akademik pengawas sekolah, sebaliknya jika kompetensi kepribadian pengawas rendah maka pelaksanaan supervisi akademik pengawas kurang.

Koefisien regresi untuk variabel kompetensi kepribadian pengawas menunjukkan nilai probabilitas $(p)$ kurang dari nilai- $\alpha=0,05$ artinya koefisien regresi dalam model untuk variabel kompetensi kepribadian pengawas bersifat signifikan. Dengan demikian dapat disimpulkan bahwa variabel kompetensi kepribadian pengawas berpengaruh positif terhadap pelaksanaan supervisi akademik pengawas. Hal tersebut mengindikasikan bahwa apabila kompetensi kepribadian pengawas meningkat maka pelaksanaan supervisi akademik pengawas akan meningkat pula. Penelitian yang dilakukan sebelumnya oleh (Amanda et al., 2017) juga menyimpulkan bahwa kompetensi kepribadian pengawas berpengaruh terhadap kinerja guru. Hal ini sekaligus membenarkan teori yang mengatakan pengawas yang sukses melaksanakan tugasnya, jika ia memiliki sifat-sifat kepribadian yang diterima dalam pergaulan sesama kerabat kerja. Besar pengaruh kompetensi kepribadian terhadap pelaksanaan supervisi akademik pengawas pada SMA di Kabupaten Luwu adalah sebesar 17,9\% dan sisanya dipengaruhi oleh variabel lain akan tetapi kompetensi kepribadian berpengaruh secara positif dan signifikan terhadap pelaksanaan supervisi akademik pengawas.

Hasil analisis inferensial dengan uji korelasi parsial antara kompetensi sosial pengawas dengan pelaksanaan supervisi akademik pengawas sekolah dengan memperhitungkan kompetensi kepribadian pengawas sekolah menunjukkan adanya arah hubungan yang positif. Dengan demikian dapat diartikan bahwa semakin tinggi kompetensi sosial pengawas maka semakin baik pula pelaksanaan supervisi akademik pengawas sekolah, sebaliknya jika kompetensi sosial pengawas rendah maka pelaksanaan supervisi akademik pengawas kurang.

Hasil analisis yang dilakukan pada pengujian hipotesis dengan menggunakan analisis regresi ganda menjelaskan keberartian koefisiensi regresi dalam model untuk variabel kompetensi sosial pengawas. Nilai probabilitas yang diperoleh klebih kecil dari $\alpha=0,05$ yang berarti koefisien regresi dalam model untuk variabel kompetensi sosial pengawas adalah berarti (signifikan). Dengan demikian dapat disimpulkan bahwa variabel kompetensi sosial pengawas berpengaruh positif terhadap pelaksanaan supervisi akademik pengawas. Hal tersebut mengindikasikan bahwa apabila kompetensi sosial pengawas meningkat maka pelaksanaan supervisi akademik pengawas akan meningkat pula.

Hal ini sejalan dengan analisis deskriptif yang memberikan informasi kompetensi sosial pengawas yang berada pada kategori tinggi yang diikuti dengan pelaksanaan supervisi akademik pengawas yang juga berada pada kategori baik. Besar pengaruh kompetensi sosial terhadap pelaksanaan supervisi akademik pengawas pada SMA di Kabupaten Luwu adalah sebesar 37,3\% dan sisanya dipengaruhi oleh variabel lain akan tetapi kompetensi sosial berpengaruh secara positif dan signifikan terhadap pelaksanaan supervisi akademik pengawas. Hal ini sejalan dengan penelitian yang dilakukan oleh Putu Deby Verayanti, dkk (2014) yang menyimpulkan bahwa kompetensi sosial berpengaruh secara positif dan signifikan terhadap kinerja Pegawai Negeri Sipil Di Badan Kepegawaian Daerah Di Kabupaten Buleleng. Hasil penelitian ini (Ferilli, Sacco, \& Noda, 2015) menunjukkan bahwa keterampilan sosial dan prestasi kerja pengawas memiliki keeratan hubungan. Menurut Pidarta (2009) hubungan yang baik akan membangun interaksi dalam suasana yang akrab dan komunikatif yang menggambarkan 
karakteristik pengawas dalam aspek sosial membantu meningkatkan kualitas supervisi dan mampu mengatasi berbagai problem pendidikan dan pengajaran dengan baik. Hal ini menunjukkan bahwa terdapat pengaruh yang signifikan kompetensi sosial terhadap pelaksanaan supervisi akademik pengawas.

\section{SIMPULAN}

Kompetensi kepribadian pengawas pada SMA di Kabupaten Luwu dalam penelitian ini berada pada kategori sangat tinggi, kompetensi sosial pengawas pada SMA di Kabupaten Luwu berada pada kategori tinggi, serta pelaksanaan supervisi akademik pengawas pada SMA di Kabupaten Luwu berada pada kategori baik. Kompetensi kepribadian dan sosial pengawas pada SMA di Kabupaten Luwu secara bersama-sama berpengaruh positif dan signifikan terhadap pelaksanaan supervisi akademik pengawas. Kompetensi kepribadian pengawas mempunyai pengaruh positif dan signifikan terhadap pelaksanaan supervisi akademik pengawas. Kompetensi sosial pengawas mempunyai pengaruh positif dan signifikan terhadap pelaksanaan supervisi akademik pengawas.

\section{DAFTAR PUSTAKA}

Agung Iskandar, Y. (2013). Pengembangan Pola Kerja Harmonis Dan Sinergis, Antara Guru, Kepala Sekolah, dan Pengawas. Jakarta: PT. Bestari Buana Murni. Edisi Pertama.

Akib, H., \& Saleh, S. (2015). Pengaruh Kepala Sekolah Sebagai Supervisor Terhadap Kinerja Guru Di Smk Negeri 7 Makassar. Jurnal Office, 1(2), 141-147.

Amanda, M. O., Salam, R., \& Saggaf, S. (2017). Pengaruh Supervisi Kepala Sekolah Terhadap Kinerja Guru Di SMK Negeri 1 Bungoro Kabupaten Pangkep. In Prosiding Seminar Nasional Himpunan Sarjana Ilmu-ilmu Sosial (Vol. 2, pp. 149-154).

Cattelino, E., Morelli, M., Baiocco, R., \& Chirumbolo, A. (2019). From external regulation to school achievement: The mediation of self-efficacy at school. Journal of Applied Developmental Psychology, 60, 127-133. https://doi.org/https://doi.org/10.1016/j.appdev.2018.09.007

Ferilli, G., Sacco, P. L., \& Noda, K. (2015). Culture driven policies and revaluation of local cultural assets: A tale of two cities, Otaru and Yūbari. City, Culture and Society, 6(4), 135-143. https://doi.org/https://doi.org/10.1016/j.ccs.2015.05.002

Ferris, G. R., Munyon, T. P., Basik, K., \& Buckley, M. R. (2008). The performance evaluation context: Social, emotional, cognitive, political, and relationship components. Human Resource Management Review, 18(3), 146-163. 

76 Jurnal Administrare: Jurnal Pemikiran Ilmiah dan Pendidikan Administrasi Perkantoran
Volume 5 Nomor 2 Juli-Desember 2018. Hal 63-76

Inprasitha, N. (2014). Perceptions on Professional Development of Supervisors in the Nonproject and Project Schools Using Lesson Study. Procedia - Social and Behavioral Sciences, 116, 2069-2073. https://doi.org/https://doi.org/10.1016/j.sbspro.2014.01.521

Irvin, D. W., Ingram, P., Huffman, J., Mason, R., \& Wills, H. (2018). Exploring paraprofessional and classroom factors affecting teacher supervision. Research in Developmental Disabilities, 73 , 106-114. https://doi.org/https://doi.org/10.1016/j.ridd.2017.12.013

Kadarsih, S. (2014). Pengaruh Profesionalisme Dan Kompetensi Terhadap Kinerja Auditor Badan Pengawas Keuangan. Jurnal Dinamika Manajemen, 2(1), 47-58.

Montecinos, C., Walker, H., \& Maldonado, F. (2015). School administrators and university practicum supervisors as boundary brokers for initial teacher education in Chile. Teaching and Teacher Education, 49, 1-10. https://doi.org/https://doi.org/10.1016/j.tate.2015.02.011

Pidarta, M. (2009). Supervisi Pendidikan Kontekstual. Rineka Cipta.

Sagala, S. (2010). Supervisi Pembelajaran dalam Profesi Pendidikan: Membantu Mengatasi Kesulitan Guru memberikan Layanan Belajar yang Bermutu. Bandung: Alfabeta.

Sahertian, P. A. (2000). Konsep dasar \& teknik supervisi pendidikan: dalam rangka pengembangan sumber daya manusia. Penerbit Rineka Cipta.

Sudjana, N. (2011). Supervisi Pendidikan Konsep dan Aplikasinya Bagi Pengawas Sekolah. Bekasi: Binamitra Publishing.

Sudjana, N. (2012). Pengawas dan Kepengawasan: Memahami Tugas Pokok, Fungsi, Peran dan Tanggung Jawab Pengawas Sekolah. Bekasi: Binamitra Publishing. 